\title{
„Parasol noś i przy pogodzie”. Wspomnienie o Remigiuszu Kwiatkowskim (1884-1961) i jego zainteresowaniach (nie tylko) aforystyką „krainy Wiśniowego Drzewa”**
}

DOI: http://dx.doi.org/10.12775/LC.2017.063

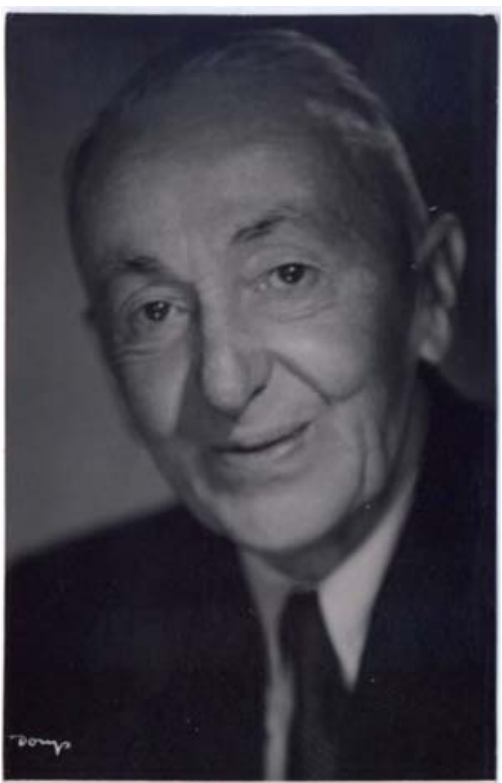

Remigiusz Kwiatkowski, 1951 rok

(fotografia autorstwa Benedykta J. Borysa; ze zbiorów Polona)

Adiunkt w Zakładzie Japonistyki Uniwersytetu Mikołaja Kopernika w Toruniu. Jego badania obejmują klasyczną literaturę i tradycyjną kulturę Japonii. E-mail: a_bed@umk.pl.

Określenie „kraina Wiśniowego Drzewa” zostało zapożyczone z opracowania Antoniego Langego pt. Sintaisi-sho: poeci nowo-japońscy, spolszczył A. Lange (z dodaniem zarysu dziejów literatury japońskiej w XIX w.), Warszawa-Kraków 1908, s. 5. 
Jako siewca idąc pośród roli, chciałbym choć jedno rzucić ziarno, bez plennych chwastów i kąkoli, jak siewca idąc pośród roli...

R. Kwiatkowski, Liryki ${ }^{1}$

W

ypływające z fin de siècle’owskiego doświadczenia kryzysu poznawczego pragnienie odkrywania obcego, innego ... egzotycznego, skłaniało do refleksji nad możliwościami synkretyzmu różnych tradycji i otwarcie się na komunikację interkulturową. Myśl ta wyrażała się choćby w słowach łacińskiej sentencji Ex Oriente lux akcentującej ówczesne literackie i artystyczne zainteresowania szeroko pojmowanym Wschodem. Ważnym miejscem na mapie Orientu w okresie Młodej Polski była Japonia, która od drugiej połowy XIX wieku przestała być jedynie odległą i odizolowaną krainą na peryferiach Azji, a wzbudzała zachwyt świeżością i oryginalnością swojej kultury. Inspiracje „japonizmem” opartym na drzeworycie ukiyoe i japońskim teatrze, które znalazły się w sferze zainteresowania nie tylko zachodnich, ale również polskich kręgów artystycznych², zdominowały i wpłynęły na kształt kanonów ówczesnej twórczości artystyczno-literackiej. Jednym z przedstawicieli tego bardzo licznego grona młodopolskich popularyzatorów orientalizmu, a w szczególności japonizmu, był Remigiusz Erazm Kwiatkowski - poeta, tłumacz, dziennikarz i autor znakomitych przedwojennych opracowań poświęconych szeroko rozumianemu Wschodowi, którego całokształt aktywności zawodowej i twórczości można byłoby scharakteryzować słowami „oddany służbie Rzeczypospolitej, zafascynowany Orientem”.

Remigiusz Kwiatkowski, pseudonim „Ajaks”, urodził się 3 czerwca 1884 roku w Warszawie jako syn urzędnika kolejowego Stanisława i Scholastyki ze Zdanowiczów. Po ukończeniu sześcioklasowego gimnazjum filologicznego rozpoczął studia historyczno-filologiczne na Uniwersytecie Warszawskim, jednocześnie aktywnie pracował na rzecz Związku Młodzieży Polskiej, elitarnej organizacji konspiracyjnej, oraz w zarządzie Bratniej Pomocy, inicjatywie samopomocowej dla niezamożnych studentów. I choć za nielegalną działalność w 1903 roku trafił do aresztu na Pawiaku, po wyjściu na wolność w dalszym ciągu czynnie działał w podziemiu, angażując się z ramienia Komitetu Walki o Szkołę Polską w strajki i tajne nauczanie. Zdemaskowanie jego nielegalnych przedsięwzięć spotkało się z szykanami ze strony władz zaborczych, które w 1908 roku doprowadziły do relegowania go z uniwersytetu i skazania na trzy miesiące więzienia w Cytadeli Warszawskiej. Definitywnym rozwiązaniem problemów z Kwiatkowskim miało okazać się wydalenie go poza granice Królestwa Polskiego, choć dla niego samego okazało się to w pewnym sensie nawet korzystne ${ }^{4}$.

1 S. Lam, Debiuty poetyckie, „Literatura i sztuka. Dodatek do Dziennika Poznańskiego” 1912, nr 12, z dn. 24 marca, s. 182.

2 M. Podraza-Kwiatkowska, Inspiracje japońskie w literaturze Młodej Polski: rekonesans, „Pamiętnik Literacki” 1983, nr 74, z. 2, s. 61 i nast.

3 Kwiatkowski publikując w licznych czasopismach, posługiwał się następującymi pseudonimami lub inicjałami: „K., r., R.K., Remigiusz K.”; por. S. Ciepłowski, Pseudonimy autorów polskich piszacych o Warszawie w latach 1795-1944, „Almanach Muzealny" 1997, nr 1, s. 244.

4 S. Sierotwiński, Kwiatkowski Remigiusz, [hasło w:] Polski słownik biograficzny, t. XVI, Zakład Narodowy im. Ossolińskich, Wrocław-Warszawa-Kraków 1971, s. 362; M. Białas, Pierwszy naczelny , "Polska Zbrojna” 2016 (wyd. specjalne „95 lat"), z dn. 5 października, s. 12. 
Poeta postanowił udać się do Moskwy, gdzie wkrótce podjął studia orientalistyczne w Instytucie Języków Wschodnich. W latach 1908-1912 dużo podróżował po Rosji, przebywał we Francji, odwiedził Persję i Turcję (1910), a także Japonię (1911). W międzyczasie poznał Janinę Rosicką ${ }^{5}$, z którą ożenił się w lutym 1912 roku. Ten nowy etap w życiu Kwiatkowskiego paradoksalnie stworzył mu możliwości dalszej pracy na rzecz ojczyzny. Działał między innymi w stowarzyszeniu Dom Polski, gdzie organizował odczyty oraz prowadził kursy języka polskiego, historii i literatury polskiej. Rozwijał również aktywność dziennikarską i korespondował z redakcjami warszawskich gazet. W 1913 roku zaangażował się w tworzenie tygodnika "Głos Polski”, którego redakcję w niedługim czasie przeniósł do Petersburga. Tam zastał go wybuch I wojny światowej, podczas której został powołany do służby w rosyjskim Dowództwie Wojsk Samochodowych. Jako chorąży w rezerwie mógł kontynuować działalność dziennikarsko-pisarską (oprócz współpracy z „Tygodnikiem Petersburskim”, w latach 1915-1916 redagował tygodnik „Sztandar” i dwutygodnik dla dzieci „Mały Sztandar”, potem też „Dziennik Polski”) i społeczną (wykładał na Polskich Wyższych Kursach Pedagogicznych ${ }^{6}$, kierował założonym przez siebie Polskim Towarzystwem Pomocy Ofiarom Wojny ${ }^{7}$ ). Po raz drugi poszedł też na studia, tym razem poszerzał wiedzę z zakresu historii sztuki i archeologii w Instytucie Archeologicznym w Petersburgu. Po rewolucji lutowej przyłączył się do Legionu Polskiego w Finlandii, w którym służył wraz z oficerami carskimi pochodzenia polskiego ${ }^{8}$.

W 1918 roku Remigiusz Kwiatkowski wrócił do Polski. Objąłkierownicwo nad Teatrem im. Staszica przy Stowarzyszeniu Robotników Chrześcijańskich w Warszawie, w którym jeszcze tego samego roku wystawiono misterium jego autorstwa zatytułowane Polska idzie. Wstąpił też w szeregi odrodzonego Wojska Polskiego. Podczas wojny polsko-bolszewickiej Kwiatkowski pracował w Sztabie Ministerstwa Spraw Wojskowych, a w 1921 roku brał udział w powstaniu i plebiscycie na Górnym Śląsku. W tym samym roku objął funkcję szefa Wydziału Wyznań Niekatolickich przy MSW i założył dziennik „Polska Zbrojna”. Przez następne kilka lat łączył służbę wojskową (awansował do stopnia podpułkownika) z pracą redaktorską. W stan spoczynku został przeniesiony po zamachu majowym w 1926 roku, co umożliwiło mu poświęcenie się w całości pracy literackiej’.

W czasie II wojny światowej poeta przynależał do Armii Krajowej na terenie Warszawy, odpowiadając za redagowanie prasy podziemnej. Po upadku Powstania Warszawskiego trafił do Częstochowy, gdzie przebywał do końca wojny. Do stolicy wrócił dopiero wiosną 1945 roku. Na początku lat pięćdziesiątych przyjął stanowisko referenta prasowego przy gabinecie premiera i zaangażował się w działalność Miczurinowskiego Ośrodka Doświadczalnego (MOD) roślin przemysłowych i specjalnych. Pracował tam niecałe dwa lata, gdyż w styczniu 1954 roku, wespół z innymi członkami MOD-u, został oskarżony

5 Jej data urodzenia jest nieznana (około 1900 roku?), a zmarła 28 stycznia 1978 roku.

6 Wykładał między innymi z Janem Baudouinem de Courtenay, Bohdanem Winiarskim; por. M. Wierzbicka, Ksiądz Edward Szwejnic - pierwszy duszpasterz akademicki. W 50 rocznicę śmierci, „Przegląd Powszechny” 1984, $\mathrm{nr} 7 / 8$ (755/756), s. 149.

7 Rozległy opis działalności tej organizacji przedstawiają artykuły: [b.a.], Polskie Towarzystwo Pomocy ofiarom Wojny w Piotrogradzie (s. 145-149); oraz [b.a.], Oddział Piotorgradzki Towarzystwa (s. 150-151), ,"Polski Kalendarz Piotrogrodzki. Rocznik llustrowany Informacyjno-Historyczno-Literacki (Praca zbiorowa tych, których los rzucił nad Newę) oraz Księga adresowa Polaków zamieszkałych w Piotrogrodzie i okolicy oraz na prowincji" 1916, R. 1, Piotrogród.

8 S. Sierotwiński, op. cit., s. 362; M. Białas, op. cit., s. 12-14.

9 S. Sierotwiński, op. cit., s. 362. 
przez Prokuraturę Generalną PRL o kierowanie związkiem przestępczym, kradzież tajnych akt wojkkowych z Ministerstwa Obrony Narodowej oraz próbę zamachu na marszałka Konstantego Rokossowskiego. Wskutek okrutnych metod śledczych i późniejszego wyroku trzech miesięcy prac w obozie karnym, bardzo podupadł na zdrowiu ${ }^{10}$. Zmarł 14 października 1961 roku. Został pochowany na Cmentarzu Wojskowym na Powązkach.

Początek dziennikarsko-literackiej twórczości Remigiusza Kwiatkowskiego przypada na okres jego studiów na Uniwersytecie Warszawskim. Właśnie wtedy ogłosił na łamach tygodnika „Wędrowiec” debiutancki wiersz Tam ptyńmy, kędy jasny ląd i zaczął redagować akademickie pismo „Zarzewie”. W 1905 roku, drukiem Synów St. Niemiry, wydał też swoją pierwszą książkę zatytułowaną Złote myśli Mikołaja Reja ${ }^{11}$. Jednak to nie odniesienia do utworów polskich mistrzów pióra zdominowały jego działalność poetycką, a dojrzewająca w nim fascynacja Orientem. Szczególnym przedmiotem jego zainteresowań stała się tematyka japońska, relatywnie najbardziej odznaczająca się na tle całej bibliografii jego dzieł inspirowanych Wschodem.

Można by rzec, że na przełomie XIX i XX wieku Europa rzeczywiście odkryła „starą, barbarzyńską Japonię" ${ }^{2}$, a odwołania do kultury japońskiej stały się powszechną praktyką wśród kręgów literackich, publicystycznych i artystycznych. Istotny wplyw na to zjawisko jak się podkreśla - wywarła szeroko rozumiana sztuka japońska, zatem ten aspekt kultury, który mógł podlegać percepcji bez konieczności posługiwania się japońszczyzną ${ }^{13}$. Przyjazd w 1902 roku między innymi do Warszawy, Krakowa, Lwowa - w ramach tournée po Starym Kontynencie - trupy Kawakamiego Otojirō (ze słynną aktorką Sadayakko), ukazujące się co rusz nowe publikacje poświęcone sztuce i kulturze japońskiej czy podziw świata dla transformacji Japonii w nowoczesne państwo bez wątpienia przyczyniły się do wzbudzenia fascynacji tym krajem u osiemnastoletniego wówczas Remigiusza. Nie bez znaczenia mógł być jeszcze jeden czynnik, o którym szczegółowo pisze Maria Podraza-Kwiatkowska:

Wraz z wybuchem wojny rosyjsko-japońskiej w lutym 1904 rozpoczyna się zupełnie nowy okres japońskich inspiracji w literaturze polskiej. Punkt ciężkości w zainteresowaniach Japonią przesuwa się z dziedziny sztuki i etnografii do dziedziny polityki: uwikłanie Rosji w wojnę na Wschodzie zaktywizowało bowiem społeczeństwo polskie w tym właśnie kierunku. [...]

[...] obserwacja społeczeństwa japońskiego wpłynęła na przemiany doktryny narodowej Dmowskiego powodując przesunięcie jej punktu ciężkości z jednostki na naród. Fascynację społeczeństwem japońskim, takimi jego zaletami, jak siła moralna, zdolność do najwyższych poświęceń, poczucie obowiązku i odpowiedzialności, „geniusz polityczny”, wyraził Dmowski w cyklu artykułów pt. Ex oriente lux ${ }^{14}$.

Zrozumienie przez Polaków fenomenu Japonii - przekonania, że siła narodu tkwi w nim samym jako całości, a nie w jednostce - zmieniło spojrzenie polskich elit politycznych na sposób walki o niepodległość. Ta japońska myśl wprowadziła zupełnie nową jakość również na gruncie twórczości pisarskiej polskich autorów, dzięki czemu „Japonia zaczy-

10 Ibidem.

11 Por. Złote myśli Mikołaja Reja, zebrał i ułożył R. Kwiatkowski, Warszawa 1906.

12 Jest to parafraza tytułu głośnego tekstu Zenona Przesmyckiego, Stara, barbarzyńska Japonia..., „Chimera” 1901, t. III, z. 9, s. 487-489 (przedruk w: Pro arte. Uwagi o sztuce i kulturze, Lwów 1914).

13 M. Podraza-Kwiatkowska, op. cit., s. 61.

14 Ibidem, s. 71. 
na spełniać w naszej literaturze ważną rolę: staje się sprzymierzeńcem w dziele moralnego odrodzenia społeczeństwa polskiego, pomaga kształtować postawę heroiczną, tak wyraźnie rysującą się zwłaszcza w literaturze pomiędzy rewolucją a wybuchem pierwszej wojny światowej”15. Remigiusz Kwiatkowski, który od młodzieńczych lat angażował się w działalność patriotyczną, społeczną i edukacyjną, z pewnością podzielał przekonania polskich elit politycznych. Jego poezja narodowa nawiązywała jednak bardziej do tradycji romantycznych aniżeli do stylu utworów wielu młodopolan, jak choćby Tadeusza Micińskiego, w twórczości którego „japońszczyzna” współkształtuje dwa opozycyjne nurty - dekadencki oraz odrodzeńczo-patriotyczny ${ }^{16}$. W wypadku Kwiatkowskiego „japońszczyzna” (japonizm) nie tylko współkształtowała jego twórczość, ale stanowiła jeden z dwóch równoważnych obok tematyki patriotycznej - obszarów jego zainteresowań i aktywności literackiej.

Począwszy od debiutanckiej książki, poeta do 1907 roku pisał pojedyncze teksty dla warszawskiego „Tygodnika Ilustrowanego”. Na fali ogromnego zainteresowania wszelkiego rodzaju opracowaniami przybliżającymi egzotykę i niezwykłość Japonii na ten temat zaczął pisać również Remigiusz Kwiatkowski. Za jego pierwszą pracę poświęconą problematyce japońskiej, a poprzedzoną pozycją o piśmiennictwie chińskim ${ }^{17}$, można uznać 76-stronicowe dziełko z serii „Książki dla Wszystkich” zatytułowane Literatura japońska ${ }^{18}$. Było to popularne opracowanie oparte na najobszerniejszym, jak na owe czasy, kompendium poświęconym japońskim tradycjom literackim (i nie tylko) - Historii literatury chińskiej i japońskiej ${ }^{19}$ Juliana A. Święcickiego ${ }^{20}$. Kwiatkowski w pewnym sensie dokonał przeróbki książki Święcickiego, ale nie jednej, gdyż analogicznie (i to w tym samym roku) ukazały się prace dotyczące innych literatur orientalnych ${ }^{21}$.

Przez następne dwa, trzy lata, po wyjeździe do Moskwy, Kwiatkowski również pisał (wydał między innymi poemat dramatyczny Jahwe ${ }^{22}$, odznaczony na konkursie dramatycznym „Kuriera Warszawskiego” w roku 1909), choć na chwilę zaniechał publikacji z zakresu literatur Wschodu. Podjął jednak, jak już wspomniano, w 1908 roku studia orientalistyczne i sporo podróżował po Azji. Dotarł również do Japonii. Niewątpliwie pokłosiem pobytu na Wyspach Japońskich była kolejna, choć niewielka (raptem 17-stronicowa) jego publikacja z 1911 roku zatytułowana Poezja i przyroda w Japonii23 ${ }^{2}$. Równocześnie, w tym samy roku,

\footnotetext{
15 Ibidem, s. 72.

16 Ibidem, s. 75-76.

17 Por. R. Kwiatkowski, Literatura chińska, nakł. i drukiem M. Arcta, Warszawa 1907.

18 Idem, Literatura japońska, Warszawa 1908.

19 O tym, że Kwiatkowski opierał się na opracowaniu Święcickiego, zobacz adnotację w: I. Schreiber, Polska bibliografia japonologiczna: po rok 1926, Kraków 1929, s. 30.

20 Święcicki w następujący sposób pisał na temat ówczesnego stanu znajomości japońskiej twórczości literackiej na Starym Kontynencie: „Literatura japońska jest dotychczas dla Europy przeważnie »ziemią nieznaną«; jest to las bujny a dziewiczy, w którym nie wycięto jeszcze nawet olbrzymów najcenniejszych. Ale bo też studia nad językiem i literaturą japońską zaczęły się bardzo niedawno"; por. J. A. Święcicki, Historya literatury chińskiej i japońskiej: z ilustracyami, „Biblioteka Dzieł Wyborowych”, Warszawa 1901. Warto dodać, że Święcicki jest również autorem jednego z najwcześniejszych opracowań literatury japońskiej, opublikowanej w Dziejach literatury powszechnej z ilustracjami, t. 2: Dzieje literatury średniowiecznej, oprac. J. A. Święcicki et al., Warszawa 1887, s. 594-661; wydane także niezależnie jako nadbitka pt. Literatura japońska.

${ }^{21}$ Literatura babilońsko-assyryjska (1908), Literatura egipska (1908), Literatura indyjska (1908), Literatura arabska (1908) i Literatura perska (1912), wszystkie wydane nakładem M. Arcta.

22 Por. R. Kwiatkowski, Jahwe, Moskwa 1911.

23 Idem, Poezja i przyroda w Japonii, Warszawa 1911.
} 
poeta wydał jedno ze swoich najbardziej znanych dzieł - zbiorek poezji Liryki24. Stanisław Lam w krótkiej recenzji tejże antologii pisał:

Poetą z talentem jest Remigiusz Kwiatkowski, znany tłómacz poezji chińskich i japońskich, który, o ile wiem, po raz pierwszy obecnie wystąpił z tomikiem wierszy oryginalnych. Skromną wyznaczył sobie autor rolę, wypisując na czele zbiorku te słowa:

"Jak siewca idąc pośród roli,

chciałbym choć jedno rzucić ziarno,

bez plennych chwastów i kąkoli,

jak siewca idąc pośród roli...

I jakiejkolwiek zaznam doli,

Czy sam, czy inni plon mój zgarną,

Jak siewca idąc pośród roli

Chciałbym choć jedno rzucić ziarno".

Zapewne, że je dorzuci poeta, wykazujący wielką wrażliwość na piękno i jego przejawy, reagujący też na nie żywo. Treść życia zgłębia on filozoficzną swą myślą i doszedłszy do przekonania, że „dziś życie - złuda złud” nawołuje:

„Dość już smętów i boleści,

trzeba nerwów, krwi i ciała,

trzeba tęższej, męskiej treści,

co nas dawno odleciała".

Mimo to jednak sam lubi wsłuchiwać się w modlitewne słowa ciszy, poddawać się czarownym nastrojom, patrzyć w ostatnie przy zachodzie słoneczne błyski, wiosną się cieszyć z naiwnością dziecka, z miękkością kobiety. Erotyki nie zawsze mu się udają, za mało w nich subtelności $i$ artystycznej finezyi.

Ton całego zbiorku jest bardzo niejednolity: obok rzeczy naprawdę dobrych, znajdą się dość pospolite (np. „Deszcz”), obok skończonych myślowo, niedociągnięte ani pod względem formalnym, ani zewnętrznym („Tryolety albumowe” z wyjątkiem pierwszego). Forma tryole$\mathrm{tu}^{25}$, w którą poważana ilość utworów jest przybrana, nie wszędzie bez zarzutu, a kilkanaście po sobie następujących wierszy tej samej rytmiki i budowy, nuży czasem swą jednostajnością. Verlaine i Słowacki nie jeden swój ton dołożyli do poezyi p. Kwiatkowskiego, której dotychczas brak tej bajecznej muzykalności wiersza, jaką posiadał pierwszy, oraz przepychu i giętkości słowa. Mimo te zarzuty przyznać trzeba, że autor „Liryków” ma talent niezaprzeczony ${ }^{26}$.

Interesująca uwaga Lama na temat filozoficznego zgłębiania w poezji Kwiatkowskiego życia, które ma być dla niego „złudą złud”, sygnalizuje w tej twórczości nutę beznadziei i pesymizmu. Niepewność towarzysząca przyszłości, powątpiewanie w siły zdolne wydać plon zdają się oddawać nastroje dekadenckie, co sam Lam podkreśla sugestią o mniejszym lub większym wpływie poezji Paula Verlaine’a na Liryki. Redaktor „Literatury i Sztuki” nie

\footnotetext{
24 Idem, Liryki, Moskwa 1911 (stron 144); por. „Katalog nowych książek: miesięcznik bibliograficzny Księgarni G. Gebethnera i spółki w Krakowie" 1911, R. 8, nr 11/12, s. 108.

25 Łoś tłumaczy, że triolet to spokrewniona z rondem strofa 8-wersowa o dwóch rymach i schemacie rymowym: ABaAabAB (wers pierwszy powtarza się jako czwarty i siódmy, a drugi jako ósmy). „Istotną cechą trioletu jest słodycz, niewinność i prostota, a powtarzanie jednej myśli, do której się inna przyczepia, jest szczególniejszym jej wdziękiem". Spotykany jako forma stała w poezji Mickiewicza (s. 194-195), Czesława Jankowskiego (s. 321), Lucjana Rydla (s. 333). Por. J. N. B. Łoś, Wiersze polskie w ich dziejowym rozwoju, Rzecz wydana z zasiłkiem Ministerstwa W. R. i O. P., Warszawa 1920. Jest to również forma stosowana przez Remigiusza Kwiatkowskiego w jego parafrazach mądrości Wschodu.

26 S. Lam, Debiuty poetyckie, s. 182 (ortografia oryginalna).
} 
mógł jednak dostrzec jeszcze jednej, kto wie, czy nie mniej istotnej płaszczyzny estetycznej (intertekstualnej?), która mogła mieć wpływ na utwory Remigiusza Kwiatkowskiego, mianowicie obecnego w niej dalekiego echa średniowiecznej japońskiej, buddyjskiej idei mujō (niestałość, nietrwałość) ${ }^{27}$.

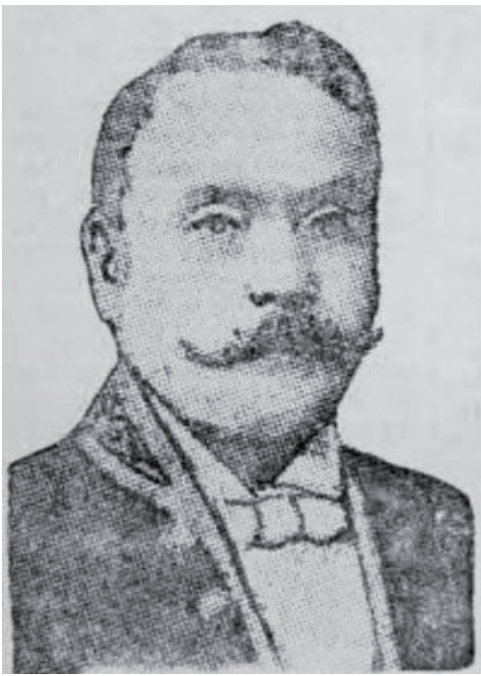

Fukuda Naohiko wicekonsul Japonii (Московскиевести, „Русскоеслово” 1909, № 59 (13 марта [28 февраля]), s. 3, [za:] С. С. Павленко, ор. cit., s. 262)

Pomijając kwestię inspiracji w Lirykach, znamienne jest również to, że - w opinii Lama - Remigiusz Kwiatkowski był doceniany jako „znany tłómacz poezji chińskich i japońskich” już w 1911 roku! Niewątpliwą sławę przyniósł mu jednak dopiero przekład jednej z najsłynniejszych antologii klasycznej literatury japońskiej - Ogura hyakunin isshu (Ogura: po jednym wierszu od stu poetów) ${ }^{28}$, którego efekty omawiał nawet $\mathrm{z}$ ówczesnym wicekonsulem japońskim w Moskwie, Fukudą Naohiko ${ }^{29}$. Pierwotnie został on opublikowany w dwóch częściach, we wrześniowym i październikowym numerze „Museionu” z 1912 roku. Pierwsza część zawiera we wstępie ogólne informacje o autorstwie zbioru, rozległe wyjaśnienie, czym jest gra w „utę-garutę”, oraz tłumaczenie 48 wierszy wraz ze zwięzłymi notkami o ich autorach ${ }^{30}$. Druga część obejmuje dopełniające całość 52 wiersze oraz zakończenie z dłuższym komentarzem, jakim rodzajem utworów są te zawarte w Chiakunin-izszu, jak również to, dlaczego posłużył się trioletem, przekładając je na język polski ${ }^{31}$. Jak naświetlał ten problem czytelnikowi:

27 Szerzej na ten temat zob. K. Olszewski, „Kolor kwiatów śála przypomina, że wszystko co rozkwita, niechybnie szczeźnie" - o wpływie nauki buddyjskiej o niestałości wszechrzeczy (mujōkan) na estetykę japońską okresu Heian (IX-XII w.), [w:] Estetyka transkulturowa, red. K. Wilkoszewska, Kraków 2004, s. 241-250.

28 Antologia krótkich wierszy japońskich (tanka) skompilowana w XIII wieku najprawdopodobniej przez arystokratę i znawcę literatury, Fujiwara no Teikę (1162-1241), który zgromadził w niej utwory wybitnych poetów. Zbiór ten wykorzystuje się po dziś dzień jako formę popularnej rozrywki, kojarzącej się przede wszystkim z noworoczną grą w karty (utagaruta). Począwszy od pracy Remigiusza Kwiatkowskiego, na przestrzeni ostatniego stulecia jeszcze kilkakrotnie fragmentarycznie przekładano wiersze z Hyakunin isshu. Pełne polskie tłumaczenie całości zbioru z oryginału starojapońskiego autorstwa Anny Zalewskiej zostało wydane w 2008 roku. Por. T. Fujiwara, Ogura hyakunin isshu, czyli Zbiór z Ogura - po jednym wierszu od stu poetów, tłum. A. Zalewska, Wydawnictwo jeżeli p to q, Poznań 2008; na temat utagaruta por. s. 11-12; wykaz publikacji zawierających wybrane tłumaczenia por. s. 12-13.

${ }^{29}$ Chiakunin-izszu, czyli Ze stu poetów po jednej pieśni(dokończenie), tłum. R. Kwiatkowski, „Museion: miesięcznik poświęcony literaturze i sztuce" 1912, R. 2, z. 10, s. 51. Fukuda Naohiko (1864-1915) był dyplomatą, sekretarzem i tłumaczem przy Konsulacie Japonii w Odessie, a w latach 1906-1909 wicekonsulem w tej placówce. W lutym 1909 roku objął stanowisko wicekonsula w Moskwie, pełniąc jednocześnie funkcję tłumacza przy Ambasadzie Japonii w Petersburgu. Por. С. Сергіївна Павленко, Консульські установив системі російскояпонських відносин (1850-тірр.-1917р.), рукопис дисертації наздобуття наукового ступеня кандидата історичних наук, Міністерство Освітиі Науки України, Дніпропетровський Національний Університет Імені Олеся Гончара, Дніпро 2016, s. 165-169, 262.

30 Chiakunin-izszu, czyli Ze stu poetów po jednej pieśni, tłum. R. Kwiatkowski, „Museion: miesięcznik poświęcony literaturze i sztuce" 1912, R. 2, z. 9, s. 60-77.

31 Ibidem, z. 10, s. 32-51. 
W przytoczeniu dźwiękowym uty celowo podkreśliłem dźwięki powtarzające się, aby wskazać, iż na takiej kombinacyi polega urok i czar poetyckiego języka w Japonii. Pragnąc odtworzyć te monotonię i powtórzenia, na jakich opiera się uta, zastosowałem dla jej przekładu tryolet, tembardziej że miniatura poetycka, jaką jest w europejskiej poezyi tryolet, najbardziej ze wszystkich artystycznych rodzajów odpowiada tej wypieszczonej przez szereg stuleci miniaturze, jaką jest w japońskiej poezyi uta. Do tego i treść wewnętrzna uty, zasadniczy każdej z nich nastrój, osiągany za pomocą powtórzeń, również w tryolecie europejskim znajduje dla siebie najlepszy odpowiednik.

$\mathrm{Z}$ takich pobudek ośmieliłem się na modernizacyę japońskiej uty. $\mathrm{O}$ ile udała mi się ta niestosowana dotychczas próba przekładania uty przez tryolet, niech sądzą inni, ja zaś od siebie przytoczę starą maksymę „feci, quod potui”.

Idąc za przykładem wydań japońskich „Chiakunin-izszu”, dołączyłem do każdego utworu krótką notatkę o poecie lub poetce ${ }^{32}$.

$\mathrm{Na}$ temat tłumaczeń wierszy tanka (inaczej mijikauta, czyli „wiersz krótki”) w Chiakunin-izszu wypowiedział się Jerzy Kwiatkowski, który analizował język poezji Jarosława Iwaszkiewicza, również skomponowanych przez niego pięciu „ut”. W opinii tego autora tworzenie „ut” stanowiło próbę „wypowiedzenia się poprzez ściśle ukanonizowany gatunek poezji lirycznej, zgoła nie istniejący w rodzimym kręgu kulturowym poety”, a ponadto „Iwaszkiewicz wywiązał się z próby tej rzetelnie pod względem formalnym, $n b$. o wiele rzetelniej niż taki specjalista w tej dziedzinie jak Remigiusz Kwiatkowski, który swoimi trioletami rozmazał uty i nadmiernie zeuropeizował, a przecież tłumaczył czy trawestował, nie - stylizował"33. Rzeczywiście, po zestawieniu tłumaczenia Remigiusza Kwiatkowskiego z przekładem Anny Zalewskiej ma się wrażenie, że po pierwsze, treściowo są to zupełnie różne wiersze, po drugie, zastosowany w Chiakunin-izszu triolet - według tłumacza „najbardziej ze wszystkich artystycznych rodzajów odpowiada[jący] tej wypieszczonej przez szereg stuleci miniaturze, jaką jest w japońskiej poezyi uta" - nijak nie oddaje ani kanonu wersyfikacyjnego tanka (5-7-5-7-7), ani charakterystycznych dla klasycznej poezji waka (rodzima poezja japońska) zabiegów stylistycznych ${ }^{34}$. Z drugiej strony należy przyznać, że właśnie taki trioletowy przekład wierszy został bardzo dobrze przyjęty przez polskich czytelników, o czym świadczy fakt, iż przez następne kilkanaście lat publikację wznawiano aż pięciokrotnie $^{35}$. Tym bardziej zaskakuje brak choćby najmniejszej wzmianki na temat Ogura hyakunin isshu u Święcickiego - w najobszerniejszym opracowaniu literatury japońskiej z początków XX wieku - pomimo ogromnej popularności tej antologii w samej Japonii.

W roku 1912 Remigiusz Kwiatkowski opublikował jeszcze jedną ciekawą pracę poświęconą poezji japońskiej. Były to Aforyzmy japońskie, które - jako esej przeplatany „uta-

\footnotetext{
32 Ibidem, s. 50-51 (ortografia oryginalna).

33 J. Kwiatkowski, Iwaszkiewicza księga przemian, „Pamiętnik Literacki” 1969, nr 60, z. 3, s. 166 . Autor zaznaczył jeszcze, że „aczkolwiek uty Iwaszkiewicza nie są pastiszami, aczkolwiek poeta potrafił nadać im piętno własnego stylu - rzecz ma raczej charakter poetyckiej zabawy, stanowi nie tyle próbę wypowiedzenia się, ile próbę sztukmistrzowską. Wzór stylizacyjny był zbyt obcy i zbyt sztywny, by mogło stać się inaczej"(s. 166-167).

34 Zagadnienie wersyfikacji i „dodatków nadzwyczajnych" (to jest tropów stylistycznych) w waka objaśniał już Święcicki; por. J. A. Święcicki, op. cit., s. 326-327.

35 Po publikacji pierwotnej wersji antologii w "Museionie”, ukazały się kolejno: Chiakunin-Izszu. Antologia japońska, Nkł. Ska Wydaw, Kraków 1913; [wyd. II] Antologja stu poetów japońskich, ułożył i wstępem opatrzył R. Kwiatkowski, Warszawa 1913; [wyd. III] Chiakunin-izszu, [ułożył Teikakjo], [tł.] Remigjusz Kwiatkowski, Warszawa-Kraków 1919; [wyd. IV] przedruk z wyd. III, 1922; Choć była krótsza noc, niż sen: antologja poezji japońskiej „Chiakunin-Izszu” czyli „Ze stu poetów po jednej pieśni”, Warszawa 1928.
} 
mi-sentencjami” - ukazały się na łamach „Wiedzy i Życia”. Poeta nie kryje w nich swojego uwielbienia dla „bogatej aforystycznej poezji japońskiej” i siły ukochania przez Japończyków tego, co ich własne ${ }^{36}$. Swoje spostrzeżenia opisał czytelnikom w postaci poniższej anegdoty:

Wśród minjatur poezji japońskiej, któremi tak ozdobili nawet szare, codzienne życie synowie i córy Kraju Wschodzącego Słońca, przednie co do treści i popularności miejsce należy się utom-aforyzmom. Rozmiłowany w nich japończyk z lubością i przy każdej nadarzającej się okazji przetyka niemi swą dziecięcą, czyniącą na europejczyku wrażenie gaworzenia mowę, lecz... o ile rozmawia ze swoimi lub pomiędzy swoimi.

- Czemu pan - pytałem niedawno - jednego z prawowiernych, choć bardzo wykształconych po europejsku synów Nipponu - tak gęsto rozsypując piękne wasze aforyzmy, nigdy nic nie ilustrujesz niemi, rozmawiając ze mną?

Skośnooki rozmówca odpowiedział na to stale jednakowym, zagadkowo nieszczerym uśmiechem (tak zawsze uśmiecha się do europejczyka każdy japończyk) i po chwili namysłu odrzekł:

- Bo przecież do was to nie przemawia, dla was to obce...

Lecz w jego słowach nieszczerych i niechętnych czułem, jak brzmiała zgoła inna odpowiedź:

- Bo to są rzeczy nasze, to perly naszej, japońskiej, mądrości i mowy, a świętości niech nie zaznaje obcy i niepoświęcony!

Tak zrozumieć należało jego wykrętną, choć pozornie logiczną odpowiedź.

I nie czułem najmniejszego uczucia żalu lub obrazy do prawowiernego syna Japonji, przeciwnie zaimponowała mi ta nieubłagana konsekwencja i siła ukochania ponad siebie tego, co japońskie, co własne. Czułem, że mówię z jednym z tych, u których każdy i wszystko jest podporządkowane zbiorowości, społeczeństwu, krajowi, narodowi, ziemi, lecz nigdy i nic sobie...

- Wy macie dużo, więcej od innych, lecz jeszcze za mało! - te słowa z ust jednego japończyka, znającego Polskę, upamiętniły się bardzo, jako charakterystyka ze strony tych, co „mają w sobie dosyć" ${ }^{37}$.

Kwiatkowski subiektywnie dostrzegał poetyckość codziennego języka Japończyków („czyniącą na europejczyku wrażenie gaworzenia mowę”), co w jego rozumieniu wynikało z przeplatania wypowiedzi „utami-aforyzmami”. Czyżby swoje spostrzeżenia oparł na znajomości z Fukudą Naohiko, gdyż to jego najpewniej miał na myśli, mówiąc o „prawowiernym, bardzo wykształconym po europejsku synu Nipponu”? Dość to jednak wypaczony pogląd, zapewne podzielany przez niejednego z współczesnych poecie autorów, którzy pozostawali pod silnym wplywem japonizmu.

Podróż Remigiusza Kwiatkowskiego po Azji zaowocowała jednak nie tylko japonikami, bowiem jej pokłosiem były także takie prace, jak Antologi chińskie ${ }^{38}$ oraz Oryentalie ${ }^{39}$, opublikowane w 1914 roku w Wydawnictwie „Głosu Polskiego”. Na temat tej drugiej publikacji Bernard Bucholc pisał w „Dzienniku Lubelskim” następująco:

Znany poeta i doskonały znawca języków wschodnich, Remigjusz Kwiatkowski, zebrał rozproszone dotychczas po czasopismach przekłady aforyzmów wschodnich i wydał je pod ogólnym

${ }^{36}$ R. Kwiatkowski, Aforyzmy japońskie, „Wiedza i Życie: bezpłatny tygodnik ilustrowany do »Orędownika«” 1912, R.1, nr 12 (wyd. z 18 grudnia), s. 2.

37 Ibidem, s. 3.

38 R. Kwiatkowski, Antologi chińskie, Petersburg 1914.

39 Idem, Oryentalie, Petersburg 1914 (127 stron; bezpłatny dodatek do „Głosu Polskiego"; seria „Biblioteka Wschodu"). 

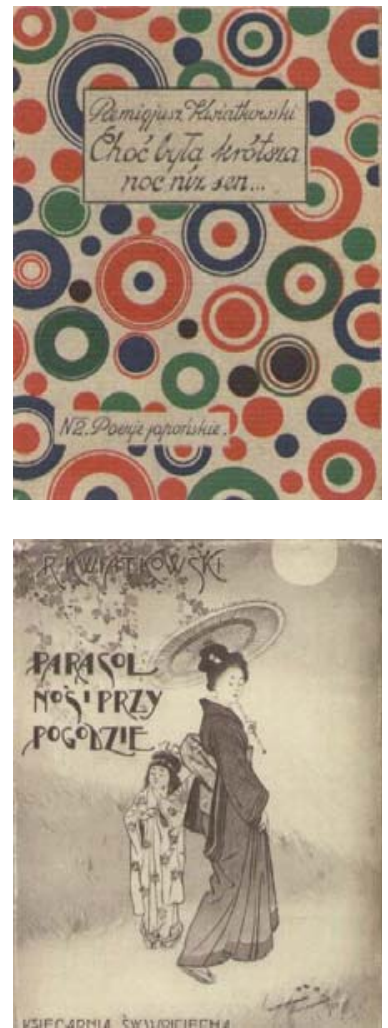

tytułem „Orjentalja”, jako dodatek bezpłatny do „Głosu polskiego”, tygodnika, wychodzącego od Nowego Roku w Petersburgu.

Aforyzmy szczególną czcią i poważaniem otoczone są na Wschodzie. I w literaturze arabskiej, i w chińskiej, i w japońskiej spotykamy się z sentencjami przybranemi w wykwintną formę wierszową o dwuch lub trzech zwrotkach. Są one tem dla narodów zachodnich, czem dla ludów zachodnich były przysłowia, z tą jednak różnicą, że gdy przysłowia pod względem formy nie posiadają wartości artystycznej, aforyzmy wschodnie są pod artystycznym względem tak piękne, tak wypieszczone, że przypominają filigranowe cacka japońskie z porcelany.

Aforyzmom wschodnim nadał Kwiatkowski w przekładzie formę trjoletu, najlepiej odpowiadają w naszym języku wypieszczonym wierszom wschodnim.

Na zbiorek złożyły się aforyzmy chińskie, japońskie, hinduskie, perskie i arabskie. Są tam sentencje o charakterze społecznym lub ogólno życiowym, mówią o kobiecie, o ludziach mądrych i glupich, o śmierci i t. d. [...]

Aforyzmów tych jest nie dużo - 127 na tyluż stronach, ale stanowią zbiorek, który czyta się z tak wielką przyjemnością, że się formalnie z książeczką tą nie chce rozstawać. Jak z powyższych przykładów wywnioskować możemy, Kwiatkowski świetnie wywiązał się z zadania: wiersz jego lekki, trudna forma trjoletu świetnie wycyzelowana, język czysty ${ }^{40}$.

W międzyczasie poeta prezentował inne prace (w roku 1917 nakładem Drukarni Polskiej wydał tomik zatytułowany Polska idzie... Poezye ${ }^{41}$, natomiast rok później tryptyk sceniczny pt. „Ku ojczyzny chwale”: z czwartego roku Wielkiej wojny ${ }^{42}$, który wyszedł drukiem i nakładem Związku Sokołów Polskich w Ameryce), łącząc działalność pisarską $\mathrm{z}$ jego wszechstronną aktywnością propolską. Z własnej inicjatywy wsparł między innymi Władysława S. Reymonta broniącego spraw Chełmszczyzny, któremu złożył propozycję przekładu jego zbioru szkiców $Z$ ziemi chetmskiej ${ }^{43}$ na rosyjski, by w postaci drukowanej broszury mogły być rozesłane wszystkim posłom Dumy (co dzięki wsparciu Józefa Eberta nastąpiło w 1912 roku) ${ }^{44}$.

Okres dwudziestolecia międzywojennego był bardzo płodnym literacko czasem dla Kwiatkowskiego. Niedługo po odzyskaniu przez Polskę niepodległości poeta wydał trzy zbiory orientalnych aforyzmów - Parasol noś i przy pogodzie... Przekłady aforyzmów wschod-

40 B. Bucholc, Z piśmiennictwa, ZZiemia Lubelska” 1914, R. 9, nr 102, s. 2 (ortografia oryginalna).

${ }^{41}$ Por. R. Kwiatkowski, Polska idzie... Poezye, okładkę i winiety rysował E. Butrymowicz, Piotrogród 1917.

42 Idem, „Ku ojczyzny chwale": z czwartego roku Wielkiej wojny. Tryptyk sceniczny, Pittsburgh, PA 1918.

43 Szkice Z ziemi chełmskiej ukazywały się w "Tygodniku llustrowanym” w roku 1909 (numery 28-490) i 1910 (numery 1-26). Jako niezależna publikacja wyszedł utwór w 1910 roku. Szerzej na temat pracy zob. J. Starnawski, Władysław Stanisław Reymont wśród piewców męczeństwa Ziemi Chełmskiej, „Acta Universitatis Lodziensis. Folia Litteraria Polonica" 2002, nr 5, s. 101-113.

44 Lublin i Lubelszczyzna w życiu i twórczości Wł. St. Reymonta - motyw unicki, materiały zamieszczone na stronie Zespołu Szkół Odzieżowo-Włókienniczych im. Wł. S. Reymonta, http://zsow.lublin.pl/ o-szkole/o-patronie/ [dostęp: 06.09.2017]. 
nich $(1921)^{45}$, I noca nie wychodź nago... Aforyzmy wschodnie $(1921)^{46}$ opublikowane nakładem poznańskiej Księgarni św. Wojciecha i Liście bambusu: poezje chińskie (1922), które wyszły nakładem Towarzystwa Wydawniczego „Ignis” ${ }^{47}$. Pracę literacką starał się wówczas godzić z obowiązkami zawodowymi w Biurze Prasowym Ministerstwa Spraw Wojskowych, o czym $\mathrm{z}$ humorem opowiadał $\mathrm{w}$ swoich wspomnieniach Stanisław Lam, który tak oto opisał swojego „wesołego szefa-poetę”:

[...] w domu narożnym przy ulicy Podwale zaczęliśmy pod egidą kapitana wówczas, a poety i dziennikarza Remigiusza Kwiatkowskiego stylem literackim opracowywać referaty. Niezwykłe to było biuro i jeszcze dziwniejsza praca w tym zespole. Kwiatkowski był typowym cyganem. Taki szef nadawał ton całej swojej ekipie. Wojskowa instytucja raczej była wesołą redakcją niż wydziałem Ministerstwa Spraw Wojskowych. [...] pracownicy więcej mieli sobie do powiedzenia $\mathrm{w}$ sprawach literatury niż o bieżących kwestiach urzędowych. Remigiusz Kwiatkowski przynosił nam swoje uty japońskie: Kobiety nie bij nawet kwiatem i Parasol noś i przy pogodzie, zręcznie tłumaczone z oryginału ... rosyjskiego $[\ldots]$.

Dyskusje były ożywione, przeplatane dowcipami i dopiero godzina jedenasta, którą obwieszczał stary zegar chrapliwym biciem, przypominała nam, że na godzinę dwunastą muszą
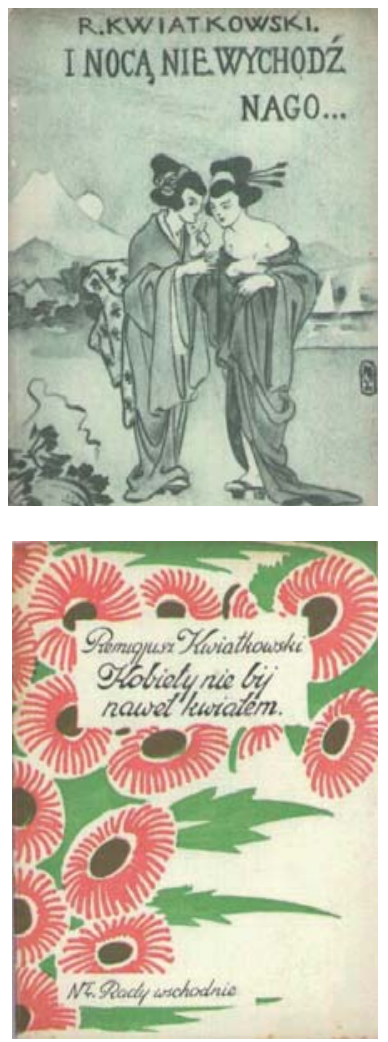
być przygotowane referaty $\mathrm{z}$ dzienników, zanoszone na Zamek $[\ldots]$ przez Remigiusza ${ }^{48}$.

Z opowieści Lama wyłania się sylwetka człowieka nie tylko rozmiłowanego w pisarstwie, ale również „duszy towarzystwa”, której rzeczywiście - mogłoby się wydawać - nieobce też były klimaty cyganerii. „[... [ Remigiusz miał dobrą głowę, a trunkiem nie gardzi1"49, i kiedy odwiedzał wraz z kolegami-literatami ulubioną knajpkę u Arkuszewskiego przy ulicy Miodowej, tryskał nierzadko humorem, co „przy jego normalnie wesołym usposobieniu równało się już szaleństwu"50.

Ten okres życia poety zakończył się wraz z zamachem majowym w 1926 roku, bowiem wtedy mógł on w pełni powrócić do pracy literackiej. Począwszy od tego też roku, na przestrzeni czterech lat wyszło pięć jego tomików zainspirowanych orientalną aforystyką. Jako pierwsza praca, wydana własnymi środkami, ukazała się antologia Nie zaglądaj za parawan $^{51}$. Następnie Kwiatkowski sięgnął po źródła koreańskie, zebrane w dziele zatytułowanym A żólty żóttej niech sobie szuka: sagi koreańskie $z$ kraju białych łabędzi $i^{52}$. Pod koniec

45 Parasol noś i przy pogodzie... Przekłady aforyzmów wschodnich, tłum. i oprac. R. Kwiatkowski, Warszawa 1921.

46 I noca nie wychodź nago...: aforyzmy wschodnie, ser. 2, tłum. i oprac. R. Kwiatkowski, Poznań 1921.

47 Liście bambusu: poezje chińskie, tłum. R. Kwiatkowski, Warszawa 1922.

48 S. Lam, Życie wśród wielu, Warszawa 1968, s. 233-234.

49 Ibidem, s. 234.

50 Ibidem, s. 235.

51 Nie zagladaj za parawan, wybór i przekł. R. Kwiatkowski, Warszawa 1926.

52 R. Kwiatkowski, A żółty żółtej niech sobie szuka: sagi koreańskie z kraju białych łabędzi, Warszawa 1928. 

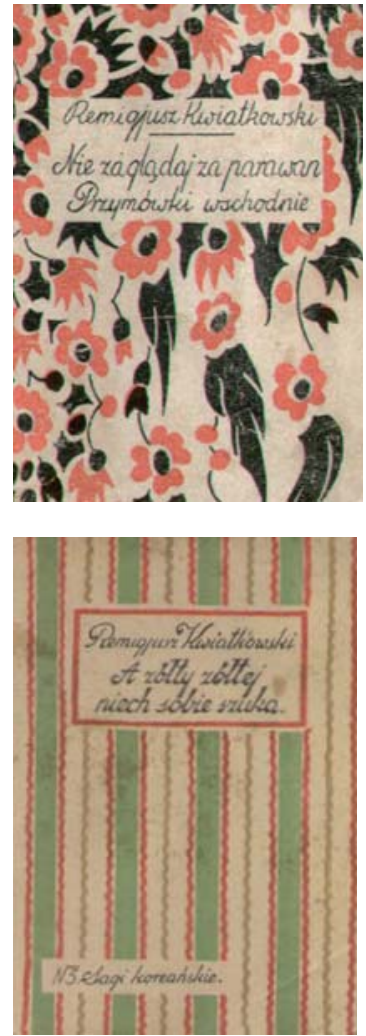

lat dwudziestych ukazały się jeszcze trzy inne zbiory w 1928 roku Kobiety nie bij nawet kwiatem: rady i uwagi wschodnie o kobiecie i miłości ${ }^{53}$, natomiast w 1929 roku Mój jedyny, mój kochany nosi kaftan $z$ cze-sun-czy $y^{54}$ oraz Nie zagladaj za para$w a n^{55}$. Wymienione tytuły świadczą o bogactwie tematyki, do której Kwiatkowski się odwoływał. Rodzi się jednak pytanie, jaka de facto - poza czysto poetycką - jest wartość orientalistyczna wymienionych zbiorów?

Henryk Markiewicz w swoim artykule $O$ polskich mistyfikacjach literackich z 1994 roku wspomina między innymi o problemie autentyzmu w inspirowanych Dalekim Wschodem utworach Kwiatkowskiego. W związku z tym, że trudno mu było rozstrzygnąć kwestię prawdziwości „zapożyczeń” orientalnych, po jakie mógł sięgać ten autor, swoją drogę do odkrycia (potencjalnie) kolejnej mistyfikacji opisał następująco:

Nie wyjaśnioną do końca pozostaje sprawa chińskich, japońskich i innych dalekowschodnich aforyzmów popularyzowanych w wierszowanej parafrazie przez Remigiusza Kwiatkowskiego. W związku z przygotowywaniem słownika "Skrzydlate słowa” zwracałem się do kilku specjalistów z prośbą o lokalizację powiedzeń: „Parasol noś i przy pogodzie” i „Kobiety nie bij nawet kwiatem”. Odpowiedzi nie było. Jedynie od prof. Mieczysława Jerzego Künstlera otrzymałem (w liście z 28.11.1992) następujące informacje:

„W klasycznej kulturze chińskiej nie używano parasola przeciw deszczowi, lecz 1. jako oznaki godności (co się oczywiście nie wiązało w ogóle z pogodą), 2. jako ochrony przed słońcem, a więc noszono go właśnie przy pogodzie. Postulat, by parasol nosić także przy pogodzie jest z chińskiego punktu widzenia absurdalny i niezrozumiały. [... ] Publikacje Kwiatkowskiego są stylizacją podszywającą się pod Orient i nie mają pierwowzorów chińskich"6 ${ }^{\text {. }}$

Trudno nie zgodzić się ze słowami profesora Mieczysława Künstlera. Z drugiej strony należy pamiętać, że, jak dotąd, nikt ze środowiska znawców Wschodu nie przeprowadził szczegółowych badań, które wskazywałyby na wykorzystywanie przez Kwiatkowskiego autentycznych, intertekstualnych nawiązań do źródeł orientalnych. Czy mamy więc do czynienia z - jak to określił Künstler - „stylizacją podszywającą się pod Orient”? Możliwe, choć to również nie może być stwierdzone bezwzględnie. Zwłaszcza jeżeli mamy świadomość, że to Kwiatkowski jako pierwszy spolszczył antologię Hyakunin isshu.

Okres wojny i czasy powojenne były dla Kwiatkowskiego czasem trudnych doświadczeń. Poeta pisał, ale coraz mniej. Ostatnim opublikowanym dziełem, które odwołuje się do stylistyki wcześniejszych zbiorów aforyzmów i przysłów ludów Wschodu, jest Pokój to ryż,

\footnotetext{
53 Idem, Kobiety nie bij nawet kwiatem: rady i uwagi wschodnie o kobiecie i miłości, Warszawa [ok. 1928].

${ }^{54}$ Mój jedyny, mój kochany nosi kaftan z cze-sun-czy: poezje chińskie, wybór i przekł. R. Kwiatkowski, Warszawa 1929.

55 R. Kwiatkowski, Nie zaglądaj za parawan: przymówki i rady wschodnie, Warszawa [1929?].

56 H. Markiewicz, O polskich mistyfikacjach literackich, „Dekada Literacka” 1994, nr 8 (91); artykuł w wersji elektronicznej dostępny na stronie „Dekady Literackiej”, http://www.dekadaliteracka.com.pl/ ?id=3181 [dostęp: 07.09.2017].
} 
a wojna - głód ${ }^{57}$, które ukazało się w 1955 roku. W rękopisach Kwiatkowskiego znajdują się jednak niewydane jeszcze prace między innymi dramaty Prorok i Żótci, tomik Nie udawaj mandaryna czy antologia przekładów turkmeńskich ${ }^{58}$.

Parafrazując słowa Stanisława Lama, nie da się zaprzeczyć, że Remigiusz Kwiatkowski był poetą i pisarzem $z$ talentem, mistrzem orientalnej aforystyki, przepojonym duchem odrodzeńczo-patriotycznym. To za sprawą jego żartobliwie filozoficznych trioletowych kompozycji będących trawestacją wschodnich sentencji poetyckich, z których niejedna weszła do potocznego języka, polscy czytelnicy zainteresowali się poezją Dalekiego Wschodu. I taki niewątpliwie był jego cel jako twórcy, mianowicie, aby swoją miłością do Orientu (a Japonii w szczególności) podzielić się z innymi. Bo jacy bylibyśmy - zdaje się pytać Kwiatkowski - gdybyśmy żyli tylko dla siebie samych, nie poświęcając się ojczyźnie, innym i swoim pasjom? Poeta pisał w Lirykach, że „jako siewca idąc pośród roli”, chciałby „choć jedno rzucić ziarno". Jak czas pokazał, nie jedno, a wiele ich rozrzucił...

Nie sztuka umrzeć, sztuka żyć

Wśród słońca, barw i woni.

Każdy potrafi w ziemi zgnić.

Nie sztuka umrzeć, sztuka żyć...

Mocno zasady tej się chwyć,

Śmierć cię i tak dogoni-

Nie sztuka umrzeć, sztuka żyć

Wśród słońca, barw i woni ${ }^{59}$.

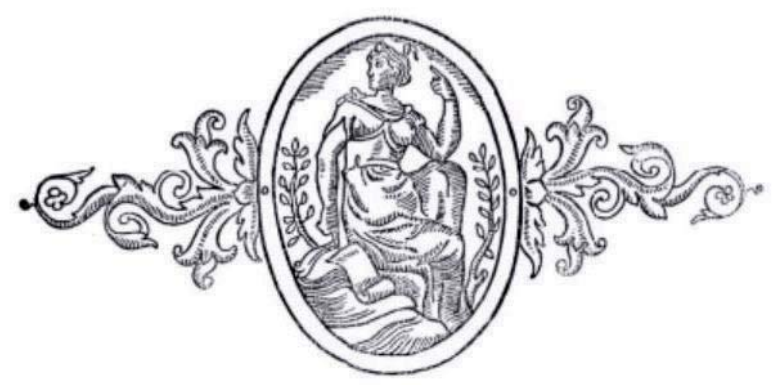

CHIAKUNIN-IZSZU

czyli

57 R. Kwiatkowski, Pokój to ryż, a wojna - głód: [aforyzmy, przysłowia i sentencje ludów Wschodu], Warszawa 1955.

58 P. Grzegorczyk, Remigiusz Kwiatkowski (1881-1961) „,Rocznik Literacki” 1961, s. 529; S. Sierotwiński, op. cit., s. 363.

59 R. Kwiatkowski, Aforyzmy japońskie, s. 3. 